\title{
Genetic Analysis of Quantitative Traits in Pepino (Solanum muricatum) in Two Growing Seasons
}

\author{
A. Rodríguez-Burruezo, J. Prohens, and F. Nuez \\ Centro de Conservación y Mejora de la Agrodiversidad Valenciana, Universidad Politécnica de \\ Valencia, Camino de Vera 14, 46022 Valencia, Spain
}

\begin{abstract}
AdDitional INDEX wORDS. new crops, heritability, stability, genotypic correlations, Solanaceae
Abstract. Twenty-six clones of pepino (Solanum muricatum Aiton) were evaluated for yield, fruit weight, fruit shape (length to width ratio), soluble solids concentration (SSC), titratable acidity (TA), and ascorbic acid concentration (AAC) over two growing seasons: autumn-winter (AW) and spring-summer (SS). Significant differences were found for the effects of clone, season, and clone $\times$ season interaction for all traits, except in the case of season for fruit shape. Mean values for yield, SSC, and AAC were higher in the AW than in the SS season, while mean fruit weight and TA were lower. Many clones (13 in AW and six in SS) had a yield higher than $30 \mathrm{t} \cdot \mathrm{ha}^{-1}$. Substantial genotypic variation was found for all traits studied except for SSC. Clones stable for all traits were detected over both seasons, except for SSC, where the differences between seasons were very high. The significant clone $\times$ season interaction for all traits indicates that selection of genotypes adapted specifically to either AW or SS seasons would maximize the response to selection. Broad sense heritabilities were highest for fruit shape and yield (>0.70), while SSC had the lowest values $(0.39$ in $\mathrm{AW}, 0.17$ in SS, and almost 0 when considering both seasons combined). For the AW season, significant fruit weight-SSC and fruit weightAAC genotypic correlations were detected; for the SS season the significant genotypic correlations were yield-SSC, fruit weight-TA, fruit shape-TA, and SSC-TA. Results suggest there are ample opportunities for improving several traits in this crop using intraspecific variation for adaptation to specific environments.
\end{abstract}

Pepino (Solanum muricatum) is an Andean herbaceous vegetable crop grown for its juicy and fragrant fruit (Anderson et al., 1996; National Research Council, 1989). Although it is a perennial in nature, pepino is usually grown as an annual. Propagation is by stem cuttings, which root easily. When ripe, pepino is usually eaten as a dessert fruit. When not fully ripe, it can be used in salads in the same way as cucumber (Cucumis sativus L.); in fact, the English name for this crop is the Spanish word for cucumber (pepino).

Pepino was an important crop in Precolumbian Andean cultures, as described by early chroniclers (Prohens et al., 1996). However, it became a neglected crop and did not reach the prominence of other New World Solanaceae like tomato (Lycopersicon esculentum Mill.), pepper (Capsicum annuum L.), potato (Solanum tuberosum L.), or tobacco (Nicotiana tabacum L.). At present, there is increasing interest in the pepino for vegetable crop diversification in several countries, in part because it is tolerant to salinity (Nuez and Ruiz, 1996; Pluda et al., 1993). Its hypotensive properties and high vitamin content (Redgwell and Turner, 1986) may contribute to an increase in demand for this fruit.

Pepino is a highly variable species for many morphological and horticultural traits (Anderson et al., 1996; Nuez and Ruiz, 1996). However, in most cases, attempts to introduce it as a new crop have been based on a single clone, thus restricting the prospects for exploiting genetic variation for selecting materials adapted to local conditions.

References on pepino breeding are scarce (Dawes and Pringle, 1983; Nuez and Ruiz, 1996). However, it has been demonstrated there are good prospects for genetic improvement of this crop (Prohens and Nuez, 1999). Crosses among unrelated parents

Received for publication 8 Jan. 01. Accepted for publication 31 Oct. 2001. We thank Comisión Interministerial de Ciencia y Tecnología (CICYT) and European Union (EU) (AGF-99-0552 and 1FD97-0137) for financing this work. Assistance provided by Verónica Marcos and Miguel Leiva-Brondo with the fieldwork is gratefully acknowledged. A. Rodríguez-Burruezo thanks Ministerio de Educación y Cultura (MEC) for a research grant. result in heterosis for yield traits (Prohens and Nuez, 1999). A dominant gene $(P)$ that confers ability for parthenocarpic fruit set and allows a significant yield increase has been reported (Prohens et al., 1998, 2001). Inheritance of fruit color has also been studied (Murray et al., 1992; Ruiz and Nuez, 2000). As a result of selection and breeding work performed to date, some commercial clones have been successful in New Zealand, California, and Spain (Dawes and Pringle, 1983; Facciola, 1990; Ruiz et al., 1997).

In Mediterranean regions, pepino is a greenhouse crop grown in either autumn-winter (AW) or spring-summer (SS) seasons (Prohens et al., 2000). Environmental differences between these two growing seasons are considerable. For example, ripening in AW takes place in winter under moderate temperatures (usually within the 5 to $25^{\circ} \mathrm{C}$ range); ripening during SS occurs in summer at higher temperatures $\left(15\right.$ to $35^{\circ} \mathrm{C}$ ) (Pluda et al., 1993; Ruiz and Nuez, 1997).

In the present investigation, we studied yield and fruit traits in a collection of pepinos during AW and SS growing seasons. Heritabilities, correlations between traits, and other genetic parameters of interest were calculated. The main objective was to provide information of relevance for pepino breeding.

\section{Materials and Methods}

Plant material. Twenty-six pepino clones from the collection of the Centro de Conservación y Mejora de la Agrodiversidad Valenciana(Universidad Politécnica de Valencia, Valencia, Spain) were used in the present study (Table 1). This collection encompasses an important diversity of origins and morphological traits of this species.

Growing CONDITIONS. All clones but one (Sm-23), were tested in both AW and SS seasons (Prohens et al., 2000) in a glasshouse in Valencia; Sm-23 was only tested in the SS season. Rooted stem cuttings were transferred to benches filled with quartz sand in February 1997 for SS and October 1998 for AW. Plants were spaced $30 \mathrm{~cm}$ apart in the bench, with $115 \mathrm{~cm}$ between bench 
centers. Temperature range was 10 to $25^{\circ} \mathrm{C}$ and 20 to $35^{\circ} \mathrm{C}$ for $\mathrm{AW}$ and SS growing seasons, respectively. Natural illumination was used for this experiment. Plants were pruned to two stems and trained with vertical strings. They were drip irrigated every $4 \mathrm{~h}$ for $5 \mathrm{~min}$. Fertilizer was applied with the irrigation water, at a rate of $1 \mathrm{~g} \cdot \mathrm{L}^{-1}$ of a commercial $15 \mathrm{~N}-2.2 \mathrm{P}-24.9 \mathrm{~K}$ water soluble fertilizer $\left(15 \mathrm{~N}-5 \mathrm{P}_{2} \mathrm{O} 5-30 \mathrm{~K}_{2} \mathrm{O}\right.$ plus micronutrients, BASF, Barcelona, Spain). Flowers were vibrated mechanically twice weekly to stimulate fruit set. Phytosanitary treatments against spider mites (Tetranychus urticae Koch) and whiteflies (Bemisia tabaci Gennadius) were performed when necessary.

EXPERIMENTAL DESIGN. A completely randomised factorial design was used, with seven clonal replicates per combination of clone and season, resulting in a total of 357 plants.

Growth measurements included the following: yield $\left(\mathrm{t} \cdot \mathrm{ha}^{-1}\right)$ calculated on the basis of the fruit yield per plant and the planting distances $(0.30 \times 1.15 \mathrm{~m})$; fruit weight (grams/fruit); fruit shape (length:width ratio); soluble solids concentration (SSC, \%), measured with a hand-held refractometer; titratable acidity (TA, $\mathrm{mmol} \cdot \mathrm{kg}^{-1}$ citric acid), determined by titrating diluted juice with $0.025 \mathrm{~N} \mathrm{NaOH}$ to the phenolphthalein end-point [results were expressed as anhydrous citric acid as this is the main acid in pepino fruit (Redgwell and Turner, 1986)]; and ascorbic acid concentration (AAC, $\mathrm{mg} \cdot \mathrm{kg}^{-1}$ ), determined by extraction with metaphosphoric acid and titrating with 2,6-dichlorophenolindolephenol dye (Association of Official Analytical Chemists, 1984).

Statistical analysis. Data were subjected to a fixed effects model analysis of variance (ANOVA). Only clones in which values for the traits could be measured in both seasons (25 for yield and 20 for the other traits) were included in the ANOVAs. The following linear model was used: $X_{i j k}=\mu+a_{i}+b_{j}+(\alpha \times \beta)_{i j}$ $+e_{i j(k)}$, where $X_{i j k}$ is the value for plant $k$ of clone $i$ and season $j$; $\mu$ is the general mean; $a_{i}$ is the effect of clone $i ; b_{j}$ is the effect of season $\mathrm{j} ;(\alpha \times \beta)_{\mathrm{ij}}$ is the effect of the interaction between clone $\mathrm{i}$ and season $\mathrm{j}$ and $\mathrm{e}_{\mathrm{ij}(\mathrm{k})}$ is the effect of plant $\mathrm{k}$ from the combination of clone $\mathrm{i}$ and season $\mathrm{j}$; $\mathrm{e}_{\mathrm{ij}(\mathrm{k})}$ represents the error term.

A fixed effects model, instead of a random effects model, ANOVA was used because AW and SS growing seasons can not be considered as random growing seasons. In fact, AW and SS represent the two growing seasons or cycles in which pepino can be grown successfully in Mediterranean climates (see Prohens et al., 2000 for a review on pepino growing seasons) and we were interested in these two particular cycles and not in others. Therefore, for our data, a fixed effects model ANOVA must be used (Nyquist, 1991; Wricke and Weber, 1986).

Clone $\times$ season interactions were studied by means of regression analysis (Dabholkar, 1992). Regression coefficients $(\beta)$ of each clone over the means of each season were calculated. Clones with $\beta$ values that do not differ significantly from 0 are considered to have static stability (Kang, 1998), or do not present significant differences between seasons for the trait under study. This type of analysis was chosen, instead of a comparison of genotypic to genotype $\times$ environment interactions, because we were not only interested in studying the importance of interactions, but also in identifying those clones in which changes in the traits studied across growing seasons are nonsignificant $(\beta=0)$.

Transformation of data to avoid scale differences caused by average differences across environments was tested (Fernández, 1992), but differences between the results obtained with transformed and nontransformed data were negligible. Transformation of data to another scale may result in a change in the occurrence, degree, and direction of the genetic effects with respect to the original scale (Dabholkar, 1992) and all discussions and subsequent calculations of genetic parameters must be made on transformed data, which usually are of controversial horticultural value. Therefore, the ANOVA and subsequent calculations based on it (stability, heritability, and genotypic correlations) were performed on nontransformed data.

HERITABILITY ESTIMATES. In vegetatively reproduced crops the entire genotype is transmitted to the subsequent generations and therefore, the main interest is on broad sense heritability $\left(\mathrm{H}^{2}\right)$ (Wricke and Weber, 1986). Heritability estimates for each season were calculated using the formula $H^{2}=\frac{\hat{\sigma}_{G}^{2}}{\hat{\sigma}_{G}^{2}+\hat{\sigma}_{E}^{2}}$

Broad-sense heritability estimates considering both seasons were also calculated. In this case, the formula used

was $H^{2}=\frac{\hat{\sigma}_{\mathrm{G}}^{2}}{\hat{\sigma}_{\mathrm{G}}^{2}+\hat{\sigma}_{\mathrm{E}}^{2}+\hat{\sigma}_{\mathrm{G} \times \mathrm{E}}^{2}}$ where $\sigma_{\mathrm{G}}{ }^{2}, \sigma_{\mathrm{E}}{ }^{2}$, and ${\sigma_{\mathrm{G} \times \mathrm{E}}^{2}}^{2}$ are the estimates of genotype, environment, and genotype $\times$ environment interaction variances, respectively. Variance component estimates were obtained from the mean squares of the corresponding ANOVA (Dabholkar, 1992). Standard errors (SEs) for heritabilities were calculated as indicated in Nyquist (1991). The equation for the SE was obtained by the Delta method as a first-order approximation of a Taylor-series expansion of the heritability function (Hanson, 1989):

$\mathrm{SE}\left(\mathrm{H}^{2}\right)=\mathrm{H}^{2} \sqrt{\frac{\sigma_{\mathrm{a}}^{2}}{\mathrm{~A}^{2}}+\frac{\sigma_{\mathrm{b}}^{2}}{\mathrm{~B}^{2}}-2 \frac{\operatorname{cov}(\mathrm{A}, \mathrm{B})}{\mathrm{A} \times \mathrm{B}}}$

When considering each season separately,

$\mathrm{A}=\frac{\mathrm{M}_{1}-\mathrm{M}_{2}}{\mathrm{r}} ; \mathrm{B}=\frac{\mathrm{M}_{1}}{\mathrm{r}}+\frac{\mathrm{M}_{2}(\mathrm{r}-\mathrm{l})}{\mathrm{r}}$

$\sigma_{\mathrm{a}}^{2}=\left(\frac{1}{\mathrm{r}}\right)^{2} \times\left[\frac{2 \mathrm{M}_{\mathrm{l}}^{2}}{\mathrm{df}_{\mathrm{Ml}}+2}+\frac{2 \mathrm{M}_{2}^{2}}{\mathrm{df}_{\mathrm{M} 2}+2}\right]$

$\sigma_{\mathrm{b}}^{2}=\left(\frac{1}{\mathrm{r}}\right)^{2} \frac{2 \mathrm{M}_{\mathrm{l}}^{2}}{\mathrm{df}_{\mathrm{Ml}}+2}+\left(1-\frac{1}{\mathrm{r}}\right)^{2} \frac{2 \mathrm{M}_{2}^{2}}{\mathrm{df}_{\mathrm{M} 2}+2}$

$\mathrm{M}_{1}$ and $\mathrm{M}_{2}$ are the mean squares between and within clones respectively, $\mathrm{dfM}_{1}$ and $\mathrm{dfM}_{2}$ are the degrees of freedom on which $\mathrm{M}_{1}$ and $\mathrm{M}_{2}$ have been calculated, and $\mathrm{r}$ is the number of replications.

When considering both seasons altogether, $\mathrm{A}=\frac{\mathrm{M}_{1}-\mathrm{M}_{2}}{\delta \times \mathrm{r}} ; \mathrm{B}=\frac{\mathrm{M}_{1}-\mathrm{M}_{2}}{\delta \times \mathrm{r}}+\frac{\mathrm{M}_{2}-\mathrm{M}_{3}}{\mathrm{r}}+\mathrm{M}_{3}$ $\sigma_{\mathrm{a}}^{2}=\left(\frac{1}{\delta \times \mathrm{r}}\right)^{2} \times\left[\frac{2 \mathrm{M}_{\mathrm{l}}^{2}}{\mathrm{df}_{\mathrm{Ml}}+2}+\frac{2 \mathrm{M}_{2}^{2}}{\mathrm{df}_{\mathrm{M} 2}+2}\right]$

$\sigma_{\mathrm{b}}^{2}=\left(\frac{1}{\delta \times \mathrm{r}}\right)^{2} \frac{2 \mathrm{M}_{1}^{2}}{\mathrm{df}_{\mathrm{Ml}}+2}+\left(\frac{\delta^{-}: 1}{\delta \times \mathrm{r}}\right)^{2} \frac{2 \mathrm{M}_{2}^{2}}{\mathrm{df}_{\mathrm{M} 2}+2}+\left(1-\frac{1}{\mathrm{r}}\right)^{2} \frac{2 \mathrm{M}_{3}^{2}}{\mathrm{df}_{\mathrm{M} 3}+2}$

$\mathrm{M}_{1}, \mathrm{M}_{2}$, and $\mathrm{M}_{3}$ are the mean squares for clone, clone $\times$ season interaction, and error respectively, $\mathrm{dfM}_{1}, \mathrm{dfM}_{2}$, and $\mathrm{dfM}_{3}$ the degrees of freedom on which $\mathrm{M}_{1}, \mathrm{M}_{2}$, and $\mathrm{M}_{3}$ have been calculated, $\delta$ the number of environments, and $r$ the number of replications.

The coefficient of genetic variation (Cv) was estimated as (Wricke and Weber, 1986, 1986):

$$
\mathrm{CV}=\sqrt{\frac{\hat{\sigma}_{\mathrm{G}}^{2}}{\hat{\mu}}} \times 100
$$

and its SE as

$\mathrm{SE}(\mathrm{CV})=\frac{\mathrm{CV} \times \sqrt{1+2(\mathrm{CV} / 100)^{2}}}{\sqrt{2 \mathrm{~N}}}$ 
where $\mathrm{N}$ is the total number of individuals for the estimate of CV.

Phenotypic, ENVIRONMENTAL, AND GENOTYPIC CORRElations. Phenotypic and environmental correlations between traits studied were calculated from correlations between clone means and the residual effects respectively (Jackson, 1994). The significance of phenotypic and environmental correlations was tested by Student's $t$ test, using the critical values for significance at $P$ $<0.05, P<0.01$, or $P<0.001$.

Genotypic correlations $\left(\mathrm{r}_{\mathrm{Gxy}}\right)$ between pairs of traits ( $\mathrm{x}$ and $\left.\mathrm{y}\right)$ were determined as (Falconer and Mackay, 1996):

$$
r_{\text {Gxy }}=\frac{r_{\text {Pxy }}-\left(\sqrt{1-\mathrm{H}_{x}^{2}} \times \sqrt{1-H_{y}^{2}}\right) \times r_{E x y}}{\sqrt{\mathrm{H}_{\mathrm{x}}^{2} \times \mathrm{H}_{\mathrm{y}}^{2}}}
$$

where $\mathrm{r}_{\mathrm{Pxy}}$ and $\mathrm{r}_{\mathrm{Exy}}$ are phenotypic and environmental correlations between traits $\mathrm{x}$ and $\mathrm{y}$, and $\mathrm{H}_{\mathrm{x}}{ }^{2}$ and $\mathrm{H}_{\mathrm{y}}{ }^{2}$ are their respective broadsense heritabilities.

Genotypic correlations are not directly estimated, and therefore their statistical significance must also be studied indirectly. Hébert et al. (1994) proposed an approximate method to study the significance of genotypic correlations. First, the SE of a genotypic correlation is calculated, using the equation (Falconer and Mackay, 1996)

$$
\operatorname{SE}\left(r_{\mathrm{Gxy}}\right)=\frac{\left(1-\mathrm{r}_{\mathrm{Gxy}}^{2}\right)}{\sqrt{2}} \times \sqrt{\frac{\mathrm{SE}\left(\mathrm{H}_{\mathrm{x}}^{2}\right) \times \mathrm{SE}\left(\mathrm{H}_{\mathrm{y}}^{2}\right)}{\mathrm{H}_{\mathrm{x}}^{2} \times \mathrm{H}_{\mathrm{y}}^{2}}}
$$

Then, the inferior limit for confidence interval of rGxy (rGxy inf) is calculated as $r_{G x y \text { inf }}=r_{G x y}-\operatorname{SE}\left(r_{G x y}\right) \times t_{(0.975, n-2)}$, where $\mathrm{t}_{(0.975, \mathrm{n}-2)}$ is the corresponding Student's $t$ test value for $\mathrm{n}-2$ degrees of freedom (df), and $\mathrm{n}$ is the number of genotypes. Then, the value for $\mathrm{r}_{\mathrm{Gxy}}$ inf is compared to the critical absolute values of the correlation coefficient that are significant at a confidence level of 0.95, 0.99, and 0.999. If the $r_{G x y}$ inf value is greater than these critical values, the genotypic correlation is then considered to be significantly different from 0 for the corresponding confidence level (Hébert et al., 1994).

\section{Results}

Descriptive STATISTICs. Clone, season, and clone(season interaction effects were significant (confidence level of $P>0.99$ ) and highly significant $(P>0.999)$ for all traits except for season effect in fruit shape (Table 2).

On average, fruit yield was higher in the AW season $(26.6$ $\left.\mathrm{t} \cdot \mathrm{ha}^{-1}\right)$ than in the SS season $\left(18.3 \mathrm{t} \cdot \mathrm{ha}^{-1}\right)$ (Table 3). In the AW season, 13 clones had a yield higher than $30 \mathrm{t} \cdot \mathrm{ha}^{-1}$, while in SS, only six clones surpassed this yield. Differences between clones were large, with yield ranging from 0 to more than $60 \mathrm{t} \cdot \mathrm{ha}^{-1}$ (Table 3).

In general, fruit weight had higher values in the SS season $(214.5 \mathrm{~g})$ than in AW (155.4 g). Differences among clones have also been important. Some clones yielded very large fruit (e.g., Sm-14), while others (e.g., Sm-5, Sm-21, and Sm-25) were small in size (Table 3 ). We found pepino clones that differed substantially between seasons in fruit weight, e.g., Sm-14, with a difference $>300 \mathrm{~g}$ (Table 3 ).

For fruit shape, variation between clones was important, ranging from elongated, with a length:width ratio $>2$ (e.g., Sm29 ) to very flattened shapes, with a ratio of $\approx 0.80$ (e.g., Sm-10 and Sm-16) (Table 3). On average, no differences were found among AW and SS seasons, although some clones showed slight differ- ences between seasons for shape; thus for clones Sm-1, Sm-4, and Sm-11, fruit were more elongated in SS than in AW, while the contrary was true in clones Sm-13 and Sm-17 (Table 3), indicating the presence of genotype $\times$ environment interactions.

SSC values were much higher in the AW season than in the SS season, with a mean difference $>2$ units (Table 4 ). Some clones showed differences between seasons $>4$ units. Variation ranges for SSC were considerably different (AW season: $7.1 \%$ to $11.7 \%$; SS season: $5.0 \%$ to $7.5 \%$ ). In the AW season, several clones (Sm19 and Sm-20) had a SSC exceeding 10\% (Table 4).

TA was slightly higher in the SS than in the AW growing season (about 15\%) (Table 4). Differences between clones have been important. TA values for pepino ranged between 7.3 and $27.1 \mathrm{mmol} \cdot \mathrm{kg}^{-1}$ of citric acid. In most comparisons, differences between seasons for the various pepino clones were not important (Table 4).

Mean AAC was higher in the AW season $\left(269 \mathrm{mg} \cdot \mathrm{kg}^{-1}\right)$ than in the SS season $190 \mathrm{mg} \cdot \mathrm{kg}^{-1}$ (Table 4). Differences among clones were considerable, with a range from 30 to $399 \mathrm{mg} \cdot \mathrm{kg}^{-1}$ (Table 4). There were clones that had considerably lower values in the SS season. Clone Sm-22 had a very low AAC, always lower than 70 $\mathrm{mg} \cdot \mathrm{kg}^{-1}$.

Stability of Traits. We found 15 clones whose regression coefficients $(\beta)$ for yield did not differ significantly from 0 . Therefore, they could be considered to have static stability for this trait (Kang, 1998). However, 10 clones were unstable for yield. In these cases, with the exception of Sm-32, $\beta$ values were always higher than 1 (Table 3 ), indicating they have a much higher yield in AW than in SS. These clones seem to be adapted to the environmental conditions present in the AW season. Thus, not surprisingly, several of the most productive clones in AW do not appear among the most productive clones of the SS season (Table 3).

In the case of fruit weight, about half of the pepino clones could be considered as having static stability. Eight of the nine clones considered unstable had a positive $\beta$ value (Table 3 ), indicating that fruit weight was higher in the SS season than in the AW season. Only Sm-14 presented a negative $\beta$ value, and had significantly heavier fruit in the AW season than in the SS season (Table 3).

Fruit shape showed, in general, an important static stability. Most clones were stable (except Sm-1, Sm-4, Sm-11, Sm-13, and Sm-17) (Table 3), showing the relatively low effect that environmental conditions had in the expression of this trait.

None of the clones studied showed static stability for SSC. Values of $\beta$ were positive and significantly different from 0 (Table 4) indicating that environmental conditions of the AW season favored a higher SSC in all clones. TA was the most stable trait in this work and virtually all clones (except Sm-10, Sm-16, and Sm-30) showed static stability (Table 4). Eight clones were unstable for AAC, and their regression coefficients were positive because of their considerably lower values in the SS season.

Heritability AND CV OF TRAITs. The highest values of heritability corresponded to fruit shape, with such values always exceeding 0.85 (Table 5). This confirms that this trait has a relatively small environmental influence, in most clones. Yield also had high values in both seasons $\left(\mathrm{H}^{2}=0.70-0.75\right)$ (Table 5), but when both seasons were considered together, heritability decreased to a medium value (0.52). Fruit weight and AAC had values for heritabilities ranging from 0.40 to 0.60 in both seasons (Table 5). When considering both seasons altogether, heritability for AAC was 0.39, while for fruit weight it did not differ 
Table 1. Origin and characteristics of the pepino clones used in the study.

\begin{tabular}{|c|c|c|}
\hline Clone & Type of material & Country of origin \\
\hline$\overline{\mathrm{Sm}-1}$ & Commercially cultivated clone & Spain \\
\hline $\mathrm{Sm}-4$ & Derived from seed of fruit purchased at a local market & Ecuador \\
\hline Sm-5 & Derived from seed of a home garden plant & Canary Islands (Spain) \\
\hline Sm-6 & Lima & United Kingdom \\
\hline Sm-7 & Otavalo & United Kingdom \\
\hline Sm-9 & Quito & United Kingdom \\
\hline Sm-10 & Derived from seed of fruit purchased at a local market & Peru \\
\hline Sm-11 & Derived from seed of fruit purchased at a specialty market & New Zealand \\
\hline Sm-13 & Derived from seed of fruit purchased at a specialty market & Portugal \\
\hline Sm-14 & Derived from seed of fruit purchased at a specialty market & Colombia \\
\hline Sm-15 & Derived from seed of fruit purchased at a local market & Ecuador \\
\hline Sm-16 & Derived from seed of an export-type cultivated clone & Chile \\
\hline Sm-17 & Derived from seed of fruit purchased at a speciality market & Colombia \\
\hline Sm-19 & Derived from seed of a home garden plant & Ecuador \\
\hline Sm-20 & Experimental hybrid clone & Ecuador $\times$ Chile \\
\hline Sm-21 & Derived from seed of fruit purchased at a specialty market & New Zealand \\
\hline Sm-22 & Derived from seed of fruit purchased at a specialty market & New Zealand \\
\hline Sm-23 & Clonal hybrid Puzol & New Zealand $x$ Chile \\
\hline Sm-24 & Experimental hybrid clone & New Zealand $x$ Chile \\
\hline Sm-25 & Clone cultivated in a home garden & Ecuador \\
\hline Sm-26 & Experimental hybrid clone & Ecuador x Chile \\
\hline Sm-28 & Sweet Round & Spain \\
\hline Sm-29 & Sweet Long & Spain \\
\hline Sm-30 & Clone cultivated in a home garden & Ecuador \\
\hline Sm-31 & Experimental hybrid clone & Chile $x$ Chile \\
\hline Sm-32 & Derived from seed of a home garden plant & Ecuador \\
\hline
\end{tabular}

statistically from 0 , probably due to an important clone $\times$ season interaction effect in this trait.

Heritability values for SSC and TA were moderate in the AW season and low in the SS season (Table 5). When considering the seasons combined, the values were very low, and did not differ significantly from 0 .

$\mathrm{CV}$ values for yield were high, being almost 100 for the SS season (Table 5). These values indicate that there are good opportunities for improving this trait. On the other hand, CV for SSC was the lowest among the traits studied, always lower than 10 (Table 5).

CV values for fruit weight, fruit shape, and AAC were moderate $(\approx 30$ to 45$)$ except for fruit weight considering both seasons combined. In this case the CV was very low (Table 5). TA showed low values of $\mathrm{CV}$, although higher than values for SSC (Table 5).

CORRELATIONS BETWEEN TRAITs. No phenotypic correlation was significant (Table 6). Environmental correlations had, in general, low values, although in some cases they were significant (Table 6). There were positive correlations between yield and fruit weight, and between SSC and AAC in both seasons. In addition, a moderate positive correlation between SSC and TA was found in the AW season (Table 6). In the SS season, one positive environmental correlation was found between TA and AAC.

Relatively high negative values were found for genotypic correlations between: fruit weight-SSC, and fruit weight-AAC in the AW season; and yield-SSC, and fruit weight-TA in the SS season (Table 6). Also, high positive genotypic correlations were noted between fruit shape-TA, and SSC-TA in the SS season.

\section{Discussion}

Genotypic variation was found for several traits in the materials studied, confirming that the pepino is a highly variable species (Heiser, 1964; Nuez and Ruiz, 1996; Prohens and Nuez, 1999). In fact, Anderson et al. (1996) suggested that pepino could be a polyphyletic species that originated from two wild South American species ( $S$. caripense Humb. \& Bonpl. ex Dunal and $S$. tabanoense Correll), which could account for such high variation.

Table 2. ANOVA table with mean squares (MSs) for the effects of season, clone, clone $\times$ season interaction, and error.

\begin{tabular}{|c|c|c|c|c|c|c|c|c|}
\hline Effect & $\mathrm{df}^{\mathrm{z}}$ & Yield & $\mathrm{df}^{\mathrm{y}}$ & $\begin{array}{c}\text { Fruit } \\
\text { wt }\end{array}$ & $\begin{array}{c}\text { Fruit shape } \\
\text { (length/width) }\end{array}$ & SSC & TA & $\mathrm{AAC}$ \\
\hline$\overline{\text { Season }(E)}$ & 24 & $5,044^{* * * *}$ & 20 & $172,127^{* * * *}$ & $0.027^{\mathrm{NS}}$ & $300.05^{* * *}$ & $284.0^{* * *}$ & $340,756^{* * *}$ \\
\hline Clone $(\mathrm{G})$ & 1 & $3,683^{* * *}$ & 1 & $35,762^{* * * *}$ & $2.055^{* * *}$ & $3.01^{* * *}$ & $137.0^{* * *}$ & $64,357^{* * * *}$ \\
\hline $\mathrm{G} \times \mathrm{E}$ & 24 & $664^{* * * *}$ & 20 & $34,863^{* * * *}$ & $0.048^{* * * *}$ & $2.65^{* * *}$ & $61.7^{* *}$ & $13,935^{* * *}$ \\
\hline Error & 301 & 135 & 253 & 6,001 & 0.018 & 0.86 & 27.8 & 5,214 \\
\hline
\end{tabular}

${ }^{\mathrm{z}}$ Degrees of freedom for yield.

yDegrees of freedom for fruit weight, fruit shape (length to width ratio), soluble solids concentration (SSC), titratable acidity (TA), and ascorbic acid concentration (AAC).

Ns, **,**** Nonsignificant or significant at $P<0.01$ or 0.001 , respectively. 
The SS and AW seasons occur under different environmental conditions (Prohens et al., 2000). Physiological mechanisms acting in one environment can be different from those acting in the other, and, penetrance, expressivities, and the mode of action of genes controlling one trait in one environment might not be the same in another environment (Herrera-Estrella and Simpson, 1990). In fact, Falconer and Mackay (1996) stated that one trait measured in two different environments should not be considered as a single trait, but as two different traits. In this way, if the expression of a genotype depends on environmental conditions, estimates of heritability and genotypic correlations may change from one environment to another (Kang, 1998; Mazer and Schick, 1991).

Several pepino clones had very low yields in both seasons, even 0 in some cases, indicating lack of adaptation to growing conditions in our region. However, many other clones showed good adaptation to the AW season, which takes place under relatively cold temperatures, under conditions similar to the mountainous areas where the pepino originated (Anderson et al., 1996). Other researchers have also observed that certain pepino clones give low yields when they are grown in environments different from those of their region of origin (Burge, 1989; Grigg et al., 1988; Heiser, 1969; Vincenzoni, 1988). Another important observation is that the highest yields were obtained with par- thenocarpic clones (Sm-11, Sm-23 and Sm-24), which were also stable for this trait. Parthenocarpy in pepino is conferred by a dominant gene $(P)$, and it could be used for improving pepino yield and stability (Prohens et al., 1998, 2001).

Values of heritability are only applicable to the particular population studied and to the environment where the plants have been grown (Allard, 1967). Furthermore, interpretation of heritabilities and genotypic correlations in the present study might be most affected by the fact that genotypes tested do not represent a random sample of a population. Therefore, interpretation of heritability estimates within this set of clones considered as a population must be made with some caution. Also, the variable origins of genotypes in this population might result in linkage disequilibrium, which could affect interpretation on genotypic correlations. This means that values obtained in this work may be rather meaningless if extrapolated to other populations in predicting selection response. Nonetheless, they can provide a good indication of the possibilities of improvement of the traits studied using the genotypic variation available in the species. The high values of heritability and $\mathrm{Cv}$ obtained for yield indicate there are ample opportunities for developing new cultivars with high yield using the genotypic variation within the species, as it has been found in the present experiment. Although in this study values of heritability are overestimated because for each growing season

Table 3. Yield, fruit weight, and fruit shape for regression coefficient $(\beta)$ over the environmental mean and value of $F$ statistic for testing $\beta$ deviation from 0 for pepino clones studied in the autumn-winter (AW) and spring-summer (SS) seasons.

\begin{tabular}{|c|c|c|c|c|c|c|c|c|c|c|c|c|}
\hline \multirow[b]{2}{*}{ Clone } & \multicolumn{4}{|c|}{ Yield $\left(\mathrm{t} \cdot \mathrm{ha}^{-1}\right)$} & \multicolumn{4}{|c|}{ Fruit wt (g/fruit) } & \multicolumn{4}{|c|}{ Fruit shape (length/width) } \\
\hline & AW & SS & $\beta$ & $\mathrm{F}_{0}$ & AW & SS & $\beta$ & $\mathrm{F}_{0}$ & AW & SS & $\beta$ & $\mathrm{F}_{0}$ \\
\hline $\mathrm{Sm}-1$ & 43.9 efgh $^{\mathrm{z}}$ & $29.1 \mathrm{cde}$ & 1.79 & $4.88^{*}$ & $129.6 \mathrm{abc}$ & $328.7 \mathrm{de}$ & 3.37 & $21.47^{* * * *}$ & $1.22 \mathrm{~cd}$ & $1.39 \mathrm{~cd}$ & 7.56 & $5.11^{*}$ \\
\hline $\mathrm{Sm}-4$ & $2.7 \mathrm{ab}$ & $3.8 \mathrm{ab}$ & -0.13 & $0.03^{\mathrm{NS}}$ & $142.4 \mathrm{abcd}$ & $141.2 \mathrm{abcd}$ & -0.02 & $0.00^{\mathrm{NS}}$ & $0.90 \mathrm{ab}$ & $1.10 \mathrm{abc}$ & 9.19 & $5.80^{*}$ \\
\hline $\mathrm{Sm}-5$ & $1.1 \mathrm{ab}$ & 0 & 0.13 & $0.03^{\mathrm{NS}}$ & $28.8 \mathrm{a}$ & --- & --- & --- & $1.47 \mathrm{ef}$ & --- & --- & --- \\
\hline Sm-6 & $58.0 \mathrm{~h}$ & 42.4 ef & 1.89 & $4.98^{*}$ & $136.9 \mathrm{abc}$ & $198.3 \mathrm{abcd}$ & 1.04 & $2.35^{\mathrm{NS}}$ & $1.01 \mathrm{abc}$ & $1.06 \mathrm{abc}$ & 2.49 & $0.64^{\mathrm{NS}}$ \\
\hline $\mathrm{Sm}-7$ & $44.2 \mathrm{efgh}$ & $55.9 \mathrm{fg}$ & -1.41 & $2.27^{\mathrm{NS}}$ & $112.9 \mathrm{abc}$ & 294.7 cde & 3.07 & $16.53^{* * * *}$ & $0.93 \mathrm{ab}$ & $0.97 \mathrm{ab}$ & 1.99 & $0.33^{\mathrm{NS}}$ \\
\hline Sm-9 & 32.4 defg & $12.6 \mathrm{abc}$ & 2.39 & $7.25^{* *}$ & $112.0 \mathrm{abc}$ & 247.8 bcde & 2.30 & $9.22^{* * *}$ & $1.36 \mathrm{de}$ & $1.51 \mathrm{de}$ & 6.61 & $3.60^{\mathrm{NS}}$ \\
\hline Sm-10 & $6.1 \mathrm{ab}$ & $4.2 \mathrm{ab}$ & 0.24 & $0.10^{\mathrm{NS}}$ & $168.1 \mathrm{abcd}$ & 223.8 abcde & 0.94 & $0.78^{\mathrm{NS}}$ & $0.82 \mathrm{a}$ & $0.79 \mathrm{a}$ & -1.54 & $0.16^{\mathrm{NS}}$ \\
\hline Sm-11 & $53.9 \mathrm{gh}$ & $55.0 \mathrm{fg}$ & -0.14 & $0.03^{\mathrm{NS}}$ & $154.0 \mathrm{abcd}$ & $282.9 \mathrm{cde}$ & 2.18 & $9.00^{* * *}$ & $1.40 \mathrm{de}$ & $1.66 \mathrm{def}$ & 11.95 & $12.76^{* * * *}$ \\
\hline Sm-13 & $50.3 \mathrm{fgh}$ & $10.3 \mathrm{abc}$ & 4.83 & $32.51^{* * * *}$ & $206.3 \mathrm{~cd}$ & $162.7 \mathrm{abcd}$ & -0.74 & $0.79^{\mathrm{NS}}$ & $1.02 \mathrm{abc}$ & $0.81 \mathrm{a}$ & -9.64 & $8.31^{* * *}$ \\
\hline Sm-14 & 33.9 defg & 24.8 bcde & 1.10 & $0.92^{\mathrm{NS}}$ & $500.4 \mathrm{e}$ & $191.0 \mathrm{abcd}$ & -5.23 & $31.90^{* * *}$ & $0.99 \mathrm{ab}$ & $1.06 \mathrm{ab}$ & 3.08 & $0.72^{\mathrm{NS}}$ \\
\hline Sm-15 & $2.3 \mathrm{ab}$ & 0 & 0.28 & $0.14^{\mathrm{NS}}$ & $114.5 \mathrm{abc}$ & --- & -- & --- & $1.03 \mathrm{abc}$ & --- & --- & --- \\
\hline Sm-16 & $14.5 \mathrm{abcd}$ & $1.4 \mathrm{a}$ & 1.58 & $4.44^{*}$ & $95.1 \mathrm{abc}$ & $166.3 \mathrm{abcd}$ & 1.20 & $1.69^{\mathrm{NS}}$ & $0.85 \mathrm{ab}$ & $0.77 \mathrm{a}$ & -3.71 & $0.85^{\mathrm{NS}}$ \\
\hline Sm-17 & $11.0 \mathrm{abc}$ & $14.8 \mathrm{abc}$ & -0.47 & $0.37^{\mathrm{NS}}$ & $157.5 \mathrm{abcd}$ & $112.8 \mathrm{abc}$ & -0.76 & $0.84^{\mathrm{NS}}$ & $1.97 \mathrm{~g}$ & $1.81 \mathrm{ef}$ & -7.33 & $4.44^{*}$ \\
\hline Sm-19 & $3.2 \mathrm{ab}$ & 0 & 0.39 & $0.25^{\mathrm{NS}}$ & $54.4 \mathrm{ab}$ & --- & --- & --- & $0.99 \mathrm{ab}$ & --- & --- & --- \\
\hline Sm-20 & 35.1 defgh & 27.4 cde & 0.94 & $1.57^{\mathrm{NS}}$ & $95.9 \mathrm{abc} 1$ & 138.7 abcd & 0.72 & $1.07^{\mathrm{NS}}$ & $0.89 \mathrm{ab}$ & $0.79 \mathrm{a}$ & -4.66 & $1.64^{\mathrm{NS}}$ \\
\hline Sm-21 & 0 & $5.3 \mathrm{ab}$ & -0.64 & $0.72^{\mathrm{NS}}$ & --- & $36.6 \mathrm{ab}$ & --- & --- & --- & $0.96 \mathrm{ab}$ & --- & --- \\
\hline $\mathrm{Sm}-22$ & $2.5 \mathrm{ab}$ & $9.2 \mathrm{abc}$ & -0.81 & $1.15^{\mathrm{NS}}$ & $120.2 \mathrm{abc}$ & $112.0 \mathrm{abc}$ & -0.14 & $0.03^{\mathrm{NS}}$ & $1.63 \mathrm{f}$ & $1.52 \mathrm{de}$ & -4.84 & $1.61^{\mathrm{NS}}$ \\
\hline $\mathrm{Sm}-23^{\mathrm{y}}$ & --- & $65.6 \mathrm{~g}$ & --- & --- & --- & 277.6 bcde & --- & --- & --- & $1.80 \mathrm{ef}$ & --- & --- \\
\hline $\mathrm{Sm}-24$ & 43.9 efgh & $39.3 \mathrm{def}$ & 0.55 & $0.46^{\mathrm{NS}}$ & $199.9 \mathrm{bcd}$ & 229.5 abcde & 0.50 & $0.51^{\mathrm{NS}}$ & $1.09 \mathrm{bc}$ & $0.93 \mathrm{ab}$ & -7.15 & $3.87^{\mathrm{NS}}$ \\
\hline Sm-25 & $4.6 \mathrm{ab}$ & $9.4 \mathrm{abc}$ & -0.57 & $0.59^{\mathrm{NS}}$ & $63.3 \mathrm{abc}$ & $71.8 \mathrm{ab}$ & 0.14 & $0.03^{\mathrm{NS}}$ & $1.06 \mathrm{abc}$ & $1.11 \mathrm{abc}$ & 2.44 & $0.41^{\mathrm{NS}}$ \\
\hline Sm-26 & $48.7 \mathrm{fgh}$ & $10.5 \mathrm{abc}$ & 4.61 & $29.69^{* * * *}$ & $121.9 \mathrm{abc}$ & 249.1 bcde & 2.15 & $8.10^{* * *}$ & $1.22 \mathrm{~cd}$ & $1.19 \mathrm{bc}$ & -1.18 & $0.12^{\mathrm{NS}}$ \\
\hline Sm-28 & $24.2 \mathrm{bcde}$ & $22.3 \mathrm{abcd}$ & 0.22 & $0.09^{\mathrm{NS}}$ & $127.1 \mathrm{abc}$ & $403.1 \mathrm{e}$ & 4.67 & $41.27^{* * * *}$ & $0.87 \mathrm{ab}$ & $1.01 \mathrm{ab}$ & 6.38 & $3.36^{\mathrm{NS}}$ \\
\hline Sm-29 & 43.5 efgh & $8.8 \mathrm{abc}$ & 4.20 & $31.36^{* * *}$ & $117.3 \mathrm{abc}$ & 272.5 bcde & 2.62 & $11.04^{* * *}$ & $2.35 \mathrm{~h}$ & $2.40 \mathrm{~g}$ & 2.44 & $0.58^{\mathrm{NS}}$ \\
\hline $\mathrm{Sm}-30$ & 34.4 defgh & $11.6 \mathrm{abc}$ & 2.76 & $13.56^{* * *}$ & $263.9 \mathrm{~d}$ & 239.4 bcde & -0.41 & $0.30^{\mathrm{NS}}$ & $1.97 \mathrm{~g}$ & $1.89 \mathrm{f}$ & -3.35 & $0.93^{\mathrm{NS}}$ \\
\hline $\mathrm{Sm}-31$ & $28.7 \mathrm{cdef}$ & $2.5 \mathrm{ab}$ & 3.17 & $16.54^{* * *}$ & $125.5 \mathrm{abc}$ & $301.3 \mathrm{cde}$ & 2.97 & $10.30^{* *}$ & $1.51 \mathrm{ef}$ & $1.62 \mathrm{def}$ & 4.80 & $1.74^{\mathrm{NS}}$ \\
\hline $\mathrm{Sm}-32$ & 40.4 efgh & $56.2 \mathrm{fg}$ & -1.92 & $5.12^{*}$ & $113.0 \mathrm{abc}$ & $137.6 \mathrm{abcd}$ & 0.42 & $0.25^{\mathrm{NS}}$ & $1.00 \mathrm{abc}$ & $1.12 \mathrm{abc}$ & 5.48 & $2.27^{\mathrm{NS}}$ \\
\hline Mean & 26.6 & 18.3 & & & 155.4 & 214.6 & & & 1.24 & 1.26 & & \\
\hline $\mathrm{I}^{\mathrm{x}}$ & 4.1 & -4.1 & & & -29.6 & 29.6 & & & -0.01 & 0.01 & & \\
\hline
\end{tabular}

${ }^{\mathrm{z}}$ Mean separation within columns by Newman-Keuls test at $P<0.05$. Values of 0 were discarded for this test.

yThis clone was only studied in the SS season.

${ }^{\mathrm{x}} \mathrm{I}=$ value of the environmental index.

Ns, ${ }^{* * *, * * *}$ Nonsignificant or significant at $P<0.05,0.01$ and 0.001 , respectively. 
only 1 year and one location have been tested (Wricke and Weber, 1986), in other studies, we found that segregating populations of hybrids among unrelated parents had high values for yield heritability (Prohens and Nuez, 1999).

Individual fruit weight between 100 and $250 \mathrm{~g}$ is considered commercially acceptable for pepino (Prohens et al., 1999). Most clones fell within this range, although in the AW season, fruit were somewhat smaller than in SS. Regarding fruit shape, most clones were round or oval, which are the most attractive shapes.

Sugar content is a very important trait in pepino, especially if fruit are going to be used as desserts (El-Zeftawi et al., 1988). We found considerable differences between clones for SSC, although differences between seasons were also important. Ripening at high temperatures, typical of the SS season, affects SSC and fruit flavor negatively (Pluda et al., 1993; Ruiz et al., 1997). Low values for SSC in the SS season limit the use of this season for obtaining pepino fruit for dessert, at least in our environmental conditions. However, in the AW season, many clones had SSC values $>8 \%$, which is considered a minimum level for acceptance by European and North American consumers (El Zeftawi et al., 1988; Prohens et al., 1999).

Values obtained for SSC heritabilities indicate that selection for this trait would be moderately efficient only in the AW season, while selection in the SS season would not be effective, as well as selection for clones with high SSC in both seasons would also be inefficient. However, because of the low CV estimates even for the AW season, we think that improvement of this trait based on the use of the intraspecific variation, would not be likely. In other works with some accessions of wild relatives (unpublished data) we found that these species present high SSC values, which could make them very interesting material to contribute to improving the flavor of the cultivated species, in the same way wild species have been used in tomato (Hewitt and Garvey, 1987; Rick, 1978).

TA was also influenced by environmental conditions, and heritability values were similar to those obtained for SSC, although CV values were higher. Therefore, selection for this trait could be a little more efficient.

Large differences between clones were found for AAC, and results show that clones with high AAC could be obtained by selection. Furthermore, heritability values for this trait indicate that selection would be effective. On the other hand, clone Sm-22 had very low values for AAC in both seasons, suggesting that ascorbic acid physiology might be altered in this clone.

Positive environmental correlations were found between yield and fruit weight in both seasons. Therefore, yield increase was not only a consequence of a higher number of fruit, but also of a

Table 4. Soluble solids concentration (SSC), titratable acidity [TA (citric acid)], and ascorbic acid concentration (AAC) for regression coefficient

$(\beta)$ over the environmental mean and value of $\mathrm{F}$ statistic for testing $\beta$ deviation from 0 for pepino clones studied in the autumn-winter (AW) and spring-summer (SS) seasons.

\begin{tabular}{|c|c|c|c|c|c|c|c|c|c|c|c|c|}
\hline \multirow[b]{2}{*}{ Clone } & \multicolumn{4}{|c|}{$\operatorname{SSC}(\%)$} & \multicolumn{4}{|c|}{$\mathrm{TA}\left(\mathrm{mmol} \cdot \mathrm{kg}^{-1}\right)$} & \multicolumn{4}{|c|}{$\operatorname{AAC}\left(\mathrm{mg} \cdot \mathrm{kg}^{-1}\right)$} \\
\hline & $\mathrm{AW}$ & SS & $\beta$ & $\mathrm{F}_{0}$ & AW & SS & $\beta$ & $\mathrm{F}_{0}$ & AW & SS & $\beta$ & $\mathrm{F}_{0}$ \\
\hline $\mathrm{Sm}-1$ & $8.8 \mathrm{abcd}^{\mathrm{z}}$ & $6.1 \mathrm{abc}$ & 1.15 & $26.94^{* * *}$ & $12.5 \mathrm{ab}$ & $16.1 \mathrm{abc}$ & 1.88 & $1.73^{\mathrm{NS}}$ & 374 ef & 237 bcde & 1.75 & $11.83^{* * *}$ \\
\hline $\mathrm{Sm}-4$ & $9.0 \mathrm{abcd}$ & $5.7 \mathrm{abc}$ & 1.41 & $31.27^{* * *}$ & $13.0 \mathrm{ab}$ & $14.1 \mathrm{abc}$ & 0.38 & $0.06^{\mathrm{NS}}$ & 311 def & $280 \mathrm{cde}$ & 0.40 & $0.47^{\mathrm{NS}}$ \\
\hline Sm-5 & $9.5 \mathrm{bcd}$ & --- & --- & --- & $21.9 \mathrm{~cd}$ & --- & --- & --- & 294 def & --- & --- & --- \\
\hline Sm-6 & 8.4 abcd & $5.6 \mathrm{abc}$ & 1.19 & $33.45^{* * *}$ & $15.1 \mathrm{abc}$ & $15.6 \mathrm{abc}$ & 0.25 & $0.04^{\mathrm{NS}}$ & 254 cdef & $113 a b c$ & 1.79 & $14.29^{* * *}$ \\
\hline Sm-7 & $9.2 \mathrm{abcd}$ & $5.0 \mathrm{a}$ & 1.80 & $61.26^{* * *}$ & $15.1 \mathrm{abc}$ & $13.5 \mathrm{abc}$ & -0.74 & $0.25^{\mathrm{Ns}}$ & 358 ef & $275 \mathrm{cde}$ & 1.05 & $3.93^{*}$ \\
\hline Sm-9 & $7.9 \mathrm{abc}$ & $6.8 \mathrm{abc}$ & 0.46 & $4.02^{*}$ & $12.5 \mathrm{ab}$ & $12.0 \mathrm{ab}$ & -0.25 & $0.03^{\mathrm{NS}}$ & 352 ef & $306 \mathrm{e}$ & 0.59 & $1.22^{\mathrm{NS}}$ \\
\hline $\mathrm{Sm}-10$ & $7.1 \mathrm{a}$ & $5.6 \mathrm{abc}$ & 0.64 & $6.37^{*}$ & $7.3 \mathrm{a}$ & $15.1 \mathrm{abc}$ & 3.91 & $5.77^{*}$ & 240 bcde & 160 abcde & 1.03 & $3.13^{\mathrm{NS}}$ \\
\hline Sm-11 & $7.9 \mathrm{abc}$ & $5.8 \mathrm{abc}$ & 0.88 & $15.65^{* * *}$ & $17.2 \mathrm{bc}$ & $15.6 \mathrm{abc}$ & -0.81 & $0.32^{\mathrm{NS}}$ & 228 bcde & 174 abcde & 0.68 & $1.65^{\mathrm{NS}}$ \\
\hline $\mathrm{Sm}-13$ & $7.3 \mathrm{a}$ & $6.0 \mathrm{abc}$ & 0.54 & $5.84^{*}$ & $13.0 \mathrm{ab}$ & $15.1 \mathrm{abc}$ & 1.01 & $0.51^{\mathrm{NS}}$ & $300 \mathrm{def}$ & $79 \mathrm{ab}$ & 2.81 & $30.45^{* * *}$ \\
\hline $\mathrm{Sm}-14$ & $7.7 \mathrm{abc}$ & $5.6 \mathrm{abc}$ & 0.88 & $13.79^{* * *}$ & $13.5 \mathrm{ab}$ & $14.1 \mathrm{abc}$ & 0.20 & $0.02^{\mathrm{NS}}$ & $154 \mathrm{bc}$ & 140 abcde & 0.17 & $0.10^{\mathrm{NS}}$ \\
\hline Sm-15 & $7.6 \mathrm{abc}$ & --- & --- & --- & $12.0 \mathrm{ab}$ & --- & --- & --- & 228 bcde & --- & --- & --- \\
\hline $\mathrm{Sm}-16$ & $7.3 \mathrm{ab}$ & $6.0 \mathrm{abc}$ & 0.57 & $4.62^{*}$ & $12.0 \mathrm{ab}$ & $22.4 \mathrm{abc}$ & 4.97 & $8.42^{* *}$ & 365 ef & $285 \mathrm{de}$ & 1.02 & $2.48^{\mathrm{NS}}$ \\
\hline Sm-17 & $7.9 \mathrm{abc}$ & $5.9 \mathrm{abc}$ & 0.90 & $15.13^{* * * *}$ & $27.1 \mathrm{~d}$ & $22.9 \mathrm{abc}$ & -2.16 & $2.11^{\mathrm{NS}}$ & $114 \mathrm{ab}$ & $122 \mathrm{abcd}$ & -0.10 & $0.03^{\mathrm{NS}}$ \\
\hline Sm-19 & $11.7 \mathrm{e}$ & --- & --- & --- & $21.9 \mathrm{~cd}$ & --- & --- & --- & 334 ef & --- & --- & --- \\
\hline Sm-20 & $10.2 \mathrm{~d}$ & $6.0 \mathrm{abc}$ & 1.81 & $56.40^{* * *}$ & $21.9 \mathrm{~cd}$ & $15.6 \mathrm{abc}$ & -2.92 & $3.54^{\mathrm{NS}}$ & 240 bcde & 189 abcde & 0.64 & $1.33^{\mathrm{NS}}$ \\
\hline Sm-21 & --- & $7.5 \mathrm{c}$ & --- & --- & --- & $25.0 \mathrm{bc}$ & --- & --- & --- & 195 abcde & --- & --- \\
\hline $\mathrm{Sm}-22$ & $7.6 \mathrm{abc}$ & $5.3 \mathrm{ab}$ & 1.01 & $15.92^{* * * *}$ & $12.0 \mathrm{ab}$ & $14.1 \mathrm{abc}$ & 1.07 & $0.43^{\mathrm{NS}}$ & $30 \mathrm{a}$ & $67 \mathrm{a}$ & -0.47 & $0.64^{\mathrm{NS}}$ \\
\hline $\mathrm{Sm}-23^{\mathrm{y}}$ & --- & $5.6 \mathrm{abc}$ & --- & --- & --- & $8.3 \mathrm{a}$ & --- & --- & --- & 232 bcde & --- & --- \\
\hline $\mathrm{Sm}-24$ & 8.6 abcd & $7.1 \mathrm{bc}$ & 0.63 & $6.91^{* *}$ & $15.1 \mathrm{abc}$ & $15.1 \mathrm{abc}$ & 0 & $0.00^{\mathrm{NS}}$ & $138 \mathrm{bc}$ & 145 abcde & -0.09 & $0.03^{\mathrm{NS}}$ \\
\hline $\mathrm{Sm}-25$ & $9.6 \mathrm{~cd}$ & $6.7 \mathrm{abc}$ & 1.26 & $25.13^{* * *}$ & $17.7 \mathrm{bc}$ & $21.3 \mathrm{abc}$ & 1.67 & $1.06^{\mathrm{NS}}$ & 352 ef & $271 \mathrm{cde}$ & 1.04 & $3.19^{\mathrm{NS}}$ \\
\hline $\mathrm{Sm}-26$ & $9.3 \mathrm{abcd}$ & $6.5 \mathrm{abc}$ & 1.21 & $29.94^{* * * *}$ & $13.5 \mathrm{ab}$ & $17.2 \mathrm{abc}$ & 1.85 & $1.69^{\mathrm{NS}}$ & $298 \mathrm{def}$ & 170 abcde & 1.63 & $10.24^{* *}$ \\
\hline $\mathrm{Sm}-28$ & $7.9 \mathrm{abc}$ & $6.3 \mathrm{abc}$ & 0.66 & $8.24^{* *}$ & $10.4 \mathrm{ab}$ & $13.0 \mathrm{abc}$ & 1.22 & $0.67^{\mathrm{NS}}$ & $399 \mathrm{f}$ & 184 abcde & 2.74 & $26.67^{* * *}$ \\
\hline $\mathrm{Sm}-29$ & $7.7 \mathrm{abc}$ & $6.7 \mathrm{abc}$ & 0.4 & $34.13^{*}$ & $13.5 \mathrm{ab}$ & $16.1 \mathrm{abc}$ & 1.19 & $0.75^{\mathrm{NS}}$ & 309 def & 195 abcde & 1.45 & $8.69^{* * *}$ \\
\hline $\mathrm{Sm}-30$ & $7.3 \mathrm{ab}$ & $5.8 \mathrm{abc}$ & 0.68 & $8.74^{* *}$ & $15.1 \mathrm{abc}$ & $26.6 \mathrm{c}$ & 5.48 & $13.63^{* *}$ & $170 \mathrm{bcd}$ & 167 abcde & 0.04 & $0.01^{\mathrm{NS}}$ \\
\hline $\mathrm{Sm}-31$ & $9.3 \mathrm{abcd}$ & $6.2 \mathrm{abc}$ & 1.36 & $32.17^{* * * *}$ & $10.9 \mathrm{ab}$ & $10.9 \mathrm{abc}$ & 0 & $0.00^{\mathrm{Ns}}$ & $402 \mathrm{f}$ & 243 bcde & 2.02 & $12.10^{* * *}$ \\
\hline $\mathrm{Sm}-32$ & $9.1 \mathrm{abcd}$ & $5.6 \mathrm{abc}$ & 1.52 & $39.91^{* * * *}$ & $10.9 \mathrm{ab}$ & $17.2 \mathrm{abc}$ & 3.02 & $3.79^{\mathrm{Ns}}$ & $261 \mathrm{cdef}$ & 197 abcde & 0.81 & $2.14^{\mathrm{NS}}$ \\
\hline Mean & 8.3 & 6.0 & & & 14.3 & 16.5 & & & 269 & 190 & & \\
\hline $\mathrm{I}^{\mathrm{x}}$ & 1.2 & -1.2 & & & -1.1 & 1.1 & & & 40 & -40 & & \\
\hline
\end{tabular}

${ }^{\mathrm{z}}$ Mean separation within columns separated by Newman-Keuls test at $P<0.05$.

yThis clone was only studied in the SS season.

${ }^{\mathrm{x}} \mathrm{I}=$ value of the environmental index.

ns, ${ }^{* * *, * * *}$ Nonsignificant or significant at $P<0.05,0.01$ and 0.001 , respectively. 
Table 5. Broad sense heritabilities \pm SE and coefficient of genetic variation \pm SE for the traits studied, for the autumn-winter (AW) and spring-summer (SS) growing seasons, and considering both seasons combined (AW+SS).

\begin{tabular}{|c|c|c|c|c|c|c|}
\hline \multirow[b]{2}{*}{ Trait } & \multicolumn{3}{|c|}{ Heritability $\left(\mathrm{H}^{2}\right)$} & \multicolumn{3}{|c|}{ Coefficient of genetic variation (CV) } \\
\hline & AW & SS & $\mathrm{AW}+\mathrm{SS}$ & AW & SS & $\mathrm{AW}+\mathrm{SS}$ \\
\hline Yield & $0.71 \pm 0.07$ & $0.74 \pm 0.06$ & $0.52 \pm 0.10$ & $73.3 \pm 6.0$ & $96.4 \pm 9.3$ & $69.4 \pm 3.9$ \\
\hline Fruit weight & $0.53 \pm 0.10$ & $0.44 \pm 0.10$ & $0.01 \pm 0.12$ & $44.2 \pm 3.4$ & $36.7 \pm 2.8$ & $5.0 \pm 0.2$ \\
\hline Fruit shape ${ }^{z}$ & $0.92 \pm 0.02$ & $0.90 \pm 0.03$ & $0.88 \pm 0.04$ & $35.2 \pm 2.3$ & $33.8 \pm 2.7$ & $33.1 \pm 1.7$ \\
\hline $\mathrm{SSC}^{\mathrm{y}}$ & $0.39 \pm 0.10$ & $0.17 \pm 0.10$ & $0.03 \pm 0.09$ & $9.3 \pm 0.6$ & $6.2 \pm 0.4$ & $2.5 \pm 0.1$ \\
\hline $\mathrm{TA}^{\mathrm{x}}$ & $0.43 \pm 0.10$ & $0.18 \pm 0.10$ & $0.16 \pm 0.09$ & $26.2 \pm 1.6$ & $18.9 \pm 1.4$ & $16.7 \pm 0.8$ \\
\hline $\mathrm{AAC}^{\mathrm{w}}$ & $0.57 \pm 0.09$ & $0.54 \pm 0.10$ & $0.39 \pm 0.10$ & $34.5 \pm 2.3$ & $32.8 \pm 2.6$ & $28.8 \pm 1.4$ \\
\hline
\end{tabular}

${ }^{\mathrm{z}}$ Length to width ratio.

${ }^{\text {y SSC }}=$ soluble solids concentration.

${ }^{\mathrm{x}} \mathrm{TA}=$ titratable acidity.

${ }^{\mathrm{w}} \mathrm{AAC}=$ ascorbic acid concentration.

higher fruit weight. This suggests that yield potential as affected by crop management in this species has not been reached thus far, and improvement in fruit set might be the key (Prohens et al., 1998).

As with heritability, genotypic correlations between traits obtained herein must also be interpreted carefully. In the AW season, genotypic correlation between fruit weight and SSC was high, indicating these traits are related closely at the genotypic level in the clones studied. Thus, it may be difficult to develop clones with very large fruit having high SSC values for these environmental conditions. In the tomato, small fruit size favors high levels of SSC (Tighchelaar, 1986). Negative genotypic correlations between fruit weight and AAC in the AW season suggest it may also be difficult selecting clones with large fruit and high AAC.

For the SS season, the highly negative genotypic correlations between yield and SSC, and between fruit weight and TA also show the difficulty for selecting highly productive clones with sweet fruit in this season, and clones with large and acid fruit, respectively. Also, in the SS season, the high positive genotypic correlation between TA and SSC suggests that pepino genetic systems controlling TA might also have a role in SSC. In fact, this is not surprising, as organic acids are part of SSC (Salunkhe and Desai, 1984), although in our case organic acids represent only a low contribution to SSC.

The genotypic variation found for some agronomic traits in the collection of pepino clones studied indicates there are ample possibilities for selecting improved pepino materials adapted to Mediterranean climatic conditions, specially for the AW season. The important clone $\times$ season interaction indicates that breeding efforts should be directed at selecting clones adapted to specific growing seasons.

\section{Literature Cited}

Allard, R.W. 1967. Principles of plant breeding. Wiley, NewYork. Anderson, G.J., R.K. Jansen, and Y. Kim. 1996. The origin and relationships of the pepino, Solanum muricatum (Solanaceae): DNA restriction fragment evidence. Economic Bot. 50:369-380.

Association of Official Analytical Chemists. 1984. Official methods of

Table 6. Phenotypic, environmental, and genotypic correlations for the traits studied. Values in the upper and lower diagonal correspond to AW and SS growing seasons respectively.

\begin{tabular}{|c|c|c|c|c|c|c|}
\hline Trait & Yield & Fruit wt & Fruit shape & SSC & TA & $\mathrm{AAC}$ \\
\hline \multicolumn{7}{|l|}{ Phenotypic } \\
\hline Yield & & $0.137^{\mathrm{NS}}$ & $0.039^{\mathrm{NS}}$ & $0.107^{\mathrm{NS}}$ & $0.019^{\mathrm{NS}}$ & $0.133^{\mathrm{NS}}$ \\
\hline Fruit weight & $0.193^{\mathrm{NS}}$ & & $0.162^{\mathrm{NS}}$ & $-0.412^{\mathrm{Ns}}$ & $0.038^{\mathrm{NS}}$ & $-0.315^{\mathrm{Ns}}$ \\
\hline Fruit shape & $-0.140^{\mathrm{NS}}$ & $0.186^{\mathrm{NS}}$ & & $-0.269^{\mathrm{NS}}$ & $0.311^{\mathrm{NS}}$ & $-0.314^{\mathrm{NS}}$ \\
\hline SSC & $-0.263^{\mathrm{NS}}$ & $-0.014^{\mathrm{NS}}$ & $0.156^{\mathrm{NS}}$ & & $0.285^{\mathrm{NS}}$ & $0.291^{\mathrm{NS}}$ \\
\hline TA & $-0.230^{\mathrm{NS}}$ & $-0.252^{\mathrm{NS}}$ & $0.266^{\mathrm{NS}}$ & $-0.002^{\mathrm{NS}}$ & & $-0.353^{\mathrm{NS}}$ \\
\hline AAC & $-0.078^{\mathrm{NS}}$ & $0.150^{\mathrm{NS}}$ & $-0.038^{\mathrm{NS}}$ & $0.213^{\mathrm{NS}}$ & $-0.006^{\mathrm{NS}}$ & \\
\hline \multicolumn{7}{|l|}{ Environmental } \\
\hline Yield & & $0.414^{* * * *}$ & $-0.063^{\mathrm{NS}}$ & $-0.189^{\mathrm{NS}}$ & $-0.228^{\mathrm{NS}}$ & $-0.085^{\mathrm{NS}}$ \\
\hline Fruit weight & $0.455^{* * *}$ & & $0.217^{\mathrm{Ns}}$ & $-0.009^{\mathrm{NS}}$ & $-0.013^{\mathrm{NS}}$ & $0.037^{\mathrm{NS}}$ \\
\hline Fruit shape & $-0.087^{\mathrm{NS}}$ & $0.023^{\mathrm{NS}}$ & & $-0.098^{\mathrm{NS}}$ & $0.013^{\mathrm{NS}}$ & $0.123^{\mathrm{NS}}$ \\
\hline SSC & $0.037^{\mathrm{NS}}$ & $0.195^{\mathrm{NS}}$ & $-0.019^{\mathrm{NS}}$ & & $0.489^{* * *}$ & $0.284^{*}$ \\
\hline TA & $-0.044^{\mathrm{NS}}$ & $-0.031^{\mathrm{NS}}$ & $-0.185^{\mathrm{NS}}$ & $-0.168^{\mathrm{NS}}$ & & $-0.193^{\mathrm{NS}}$ \\
\hline AAC & $0.074^{\mathrm{NS}}$ & $-0.090^{\mathrm{NS}}$ & $-0.029^{\mathrm{NS}}$ & $0.275^{*}$ & $0.322^{*}$ & \\
\hline \multicolumn{7}{|l|}{ Genotypic } \\
\hline Yield & & $-0.029^{\mathrm{NS}}$ & $0.060^{\mathrm{NS}}$ & $0.359^{\mathrm{NS}}$ & $0.205^{\mathrm{NS}}$ & $0.256^{\mathrm{NS}}$ \\
\hline Fruit weight & $0.031^{\mathrm{Ns}}$ & & $0.171^{\mathrm{NS}}$ & $-0.904^{* * *}$ & $0.094^{\mathrm{NS}}$ & $-0.602^{*}$ \\
\hline Fruit shape & $-0.155^{\mathrm{NS}}$ & $0.288^{\mathrm{NS}}$ & & $-0.416^{\mathrm{NS}}$ & $0.499^{\mathrm{NS}}$ & $-0.464^{\mathrm{NS}}$ \\
\hline SSC & $-0.804^{* * * *}$ & $-0.549^{\mathrm{NS}}$ & $0.418^{\mathrm{NS}}$ & & $-0.011^{\mathrm{NS}}$ & $0.309^{\mathrm{NS}}$ \\
\hline TA & $-0.572^{\mathrm{NS}}$ & $-0.818^{*}$ & $0.783^{* * * *}$ & $0.786^{*}$ & & $-0.585^{\mathrm{NS}}$ \\
\hline AAC & $-0.165^{\mathrm{NS}}$ & $0.215^{\mathrm{NS}}$ & $-0.046^{\mathrm{NS}}$ & $0.143^{\mathrm{NS}}$ & $-0.643^{\mathrm{NS}}$ & \\
\hline
\end{tabular}

$\overline{\mathrm{Ns}, *, * * *}$ Nonsignificant or significant at $P<0.05$ or 0.001 , respectively. 
analysis. 14th ed. Assoc. Offic. Anal. Chemists, Arlington, Va.

Burge, G.K. 1989. Fruit set in the pepino (Solanum muricatum Ait.). Scientia Hort. 41:63-68.

Dabholkar, A.R. 1992. Elements of biometrical genetics. Longman, Essex, U.K.

Dawes, S.N. and G.J. Pringle. 1983. Subtropical fruits from South and Central America, p. 33-35. In: G. Wratt and H.C. Smith (eds.). Plant breeding in New Zealand. Butterworths, Wellington, New Zealand.

El-Zeftawi, B.M., L. Brohier, L. Dooley, F.H. Goubran, R. Holmes, and B. Scott. 1988. Some maturity indices for tamarillo and pepino fruits. J. Hort. Sci. 63:163-169.

Facciola, S. 1990. Cornucopia: A source book of edible plants. Kampong Publ., Vista, Calif.

Falconer, D.S. and T.F.C. Mackay. 1996. Introduction to quantitative genetics. Longman, Essex, United Kingdom.

Fernández, G.C.J. 1992. Residual analysis and data transformationsImportant tools in statistical analysis. HortScience 27:297-300.

Grigg, F.D.W., P.R. Smith, M.A. Stenersen, and B.G. Murray. 1988. Variable pollen fertility and abnormal chromosome behaviour in the pepino (Solanum muricatum Ait., Solanaceae). Sci. Hort. 35:259-268.

Hanson, W.D. 1989. Standard errors of heritability and expected selection response. Crop Sci. 29:1561-1562.

Hébert, D., S. Fauré, and I. Olivieri. 1994. Genetic, phenotypic and environmental correlations in black medic, Medicago lupulina L., grown in three different environments. Theor. Appl. Genet. 88:604 613.

Heiser, C.B. 1964. Origin and variability of the pepino (Solanum muricatum): A preliminary report. Baileya 12:151-158.

Heiser, C.B. 1969. Nightshades: The paradoxical plants. Freesman, San Francisco.

Herrera-Estrella, L. and J. Simpson. 1990. Influence of environmental factors on photosynthetic genes, p. 133-163. In: J.G. Scandalios and T.R.F. Wright (eds.). Advances in genetics. Academic Press, New York.

Hewitt, J.O. and T.C. Garvey. 1987. Wild sources of high soluble solids, p. 45-54. In: D.J. Nevins and R.A. Jones (eds.). Plant biology. vol. 4. Tomato biotechnology. Liss, New York.

Jackson, P. 1994. Genetic relationships between attributes in sugarcane clones closely related to Saccharum spontaneum. Euphytica 79:101108.

Kang, M.S. 1998. Using genotype-by-environmental interaction for crop cultivar development. Adv. Agron. 62:199-252.

Mazer, S.J. and C.T. Schick. 1991. Constancy of population parameters for life history and floral traits in Raphanus sativus L.: Norm of reaction and the nature of genotype by environment interaction. Heredity 67:143-156.

Murray, B.G., K.R.W. Hammett, and F.D. Grigg. 1992. Seed set and breeding system in the pepino Solanum muricatum Ait., Solanaceae.
Sci. Hort. 49:83-92.

National Research Council. 1989. Lost crops of the Incas: little-known plants of the Andes with promise for worldwide cultivation. Natl. Acad. Press, Wash., D.C.

Nuez, F. and J.J. Ruiz. 1996. El pepino dulce y su cultivo. Food and Agr. Organization, Rome.

Nyquist, W.E. 1991. Estimation of heritability and prediction of selection response in plant populations. Critical Rev. Plant Sci. 10:235-322.

Pluda, D., H.D. Rabinovitch, and V. Kafkafi. 1993. Pepino dulce (Solanum muricatum Ait.) quality characteristics respond to nitrogen nutrition and salinity. J. Amer. Soc. Hort. Sci. 118:86-91.

Prohens, J. and F. Nuez. 1999. Strategies for breeding a new greenhouse crop, the pepino (Solanum muricatum Aiton). Can. J. Plant Sci. 79:269-275.

Prohens, J., J.J. Ruiz, andF. Nuez. 1996. The pepino(Solanum muricatum; Solanaceae): A new crop with a history. Economic Bot. 50:355-368.

Prohens, J., J.J. Ruiz, and F. Nuez. 1998. The inheritance of parthenocarpy and associated traits in pepino. J. Amer. Soc. Hort. Sci. 123:376380.

Prohens, J., J.J. Ruiz, and F. Nuez. 1999. Yield, earliness and fruit quality of pepino clones and their hybrids in the autumn-winter cycle. J. Sci. Food Agr. 79:340-346.

Prohens, J., J.J. Ruiz, and F. Nuez. 2000. Growing cycles for a new crop, the pepino, in the Spanish Mediterranean. Acta Hort. 523:53-60.

Prohens, J., J.J. Ruiz, and F. Nuez. 2001. Improvement of fruit setting and yield in mishqui. A review with special emphasis in genetic parthenocarpy. Acta Hort. 559:687-692.

Redgwell, R.J. and N.A. Turner. 1986. Pepino (Solanum muricatum): Chemical composition of ripe fruit. J. Sci. Food Agr. 37:1217-1222.

Rick, C.M. 1978. The tomato. Scientific Amer. 239:66-76.

Ruiz, J.J. and F. Nuez. 1997. The pepino (Solanum muricatum Ait.): An alternative crop for areas affected by moderate salinity. HortScience 32:649-652.

Ruiz, J.J. and F. Nuez. 2000. High temperatures and parthenocarpy fruit set: Misunderstandings about the pepino breeding system. J. Hort. Sci. Biotechnol. 75:161-166.

Ruiz, J.J., J. Prohens, and F. Nuez. 1997. 'Sweet Round' and 'Sweet Long': Two pepino cultivars for Mediterranean climates. HortScience 32:751-752.

Salunkhe, D.K. and B.B. Desai. 1984. Postharvest biotechnology of vegetables. vol. 1. CRC Press, Boca Raton, Fla.

Tighchelaar, E.C. 1986. Tomato breeding, p. 135-171. In: M.J. Bassett (ed.). Breeding vegetable crops. AVI, Westport, Conn.

Vincenzoni, A. 1988. Application of soilless culture for producing pepinos (Solanum muricatum). Proc. Intl. Soc. Soilless Cult. 1:465468.

Wricke, G. and W. Weber. 1986. Quantitative genetics and selection in plant breeding. De Gruyter, Berlin. 